\title{
Analysis of The Impact of E-Learning on Fifth Grade Students
}

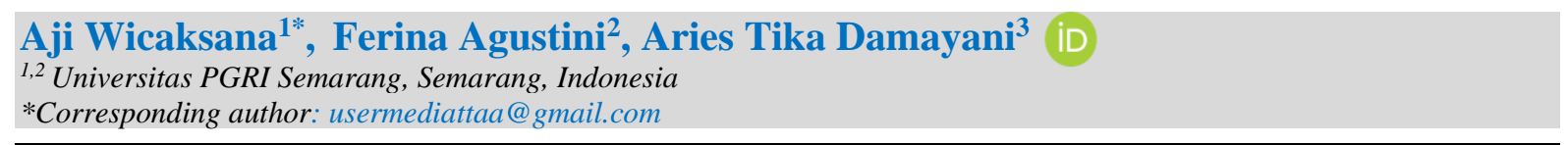

\begin{abstract}
Abstrak
Saat melaksanakan E-learning guru tidak bertatap muka secara langsung dengan siswa, padahal peran guru di sekolah sangat penting selain mengajar juga mendidik siswa. Hal ini mengakibatkan E-learning menimbulkan berbagai dampak, baik dampak negatif atau positif. Penelitian ini bertujuan untuk menganalisis pembelajaran E-learning pada siswa kelas $V$ Sekolah Dasar. Jenis penelitian ini adalah penelitian kualitatif. Teknik yang digunakan untuk mengumpulkan data yaitu observasi, wawancara, angket, dan dokumentasi. Instrument yang digunakan untuk menganalisis data yaitu kuesioner. Teknik yang digunakan dalam menganalisis data adalah deskriptif kualitatif. Teknik analisis data pada penelitian ini menggunakan tiga prosedur perolehan data yaitu reduksi data, penyajian data, dan verifikasi data. Hasil penelitian yaitu Pembelajaran E-learning dapat meningkatkan motivasi dan minat belajar siswa lebih giat. Pembelajaran E-learning lebih fleksibel bisa diakses dari mana saja. Dapat membuat siswa lebih mandiri dalam pemecahan masalahnya. Kendala yang dihadapi siswa adalah kurangnya fasilitas teknologi pendukung untuk proses pembelajaran ini seperti kualitas gadget dan sinyal di daerah sekitar sekolah.
\end{abstract}

Kata kunci: Dampak, E-Learning, Sekolah Dasar

\section{Abstract}

When implementing E-learning, the teacher does not meet face to face with students, even though the role of the teacher in schools is very important in addition to teaching and educating students. It causes E-learning to have various impacts, both negative and positive impacts. This study aimed to analyze E-learning learning in fifth-grade elementary school students. This type of research was qualitative research. The techniques used to collect data were observation, interviews, questionnaires, and documentation. The instrument used to analyze the data was a questionnaire. The technique used in analyzing the data was descriptive qualitative. The data analysis technique in this study used three data acquisition procedures, namely data reduction, data presentation, and data verification. The result of the research is that E-learning can increase students' motivation and interest in learning more actively. E-learning is more flexible and can be accessed from anywhere. Can make students more independent in solving problems. The obstacle faced by students is the lack of supporting technology facilities for this learning process, such as the quality of gadgets and signals in the area around the school.

Keywords: Impac, E-learning, Elementary School

\begin{tabular}{|c|c|c|}
\hline History: & & Publisher: Undiksha Press \\
\hline Received & : November 13, 2020 & Licensed: This work is licensed under \\
\hline Revised & : December 20, 2020 & a Creative Commons Attribution 3.0 License \\
\hline Accepted & : March 10, 2021 & (c) (†) () \\
\hline Published & : April 25, 2021 & \\
\hline
\end{tabular}

\section{Introduction}

Education has an important role in improving human resources (HR) in the face of future changes (Maesaroh, 2013; Suyadi, 2018; Widowati, 2011). Education is carried out to develop all aspects of human life. It is a shared responsibility between the community, government, and parents. The role of education is an important thing for increasing capabilities and increasing national competition in the world. A nation with a high quality of education makes human resource development develop quickly and well (Darmayasa, Jampel, \& Simamora, 2018; Nurkholis, 2013; Wirasasmita \& Hendriawan, 2020). Educational institutions, including schools, have a role in preparing students to compete in the outside world, growing globally, and having good digital literacy (Maunah, 2015; Mustikaningrum, Pramusinta, Ayu, \& Umar, 2020). The learning carried out between educators, namely teachers and students, requires many innovations that integrate technology 
(Azizah, Khuzaemah, \& Rosdiana, 2017; Lapisa et al, 2017; Taufik, 2019). Learning must continue to innovate so that students are more interested and easier to achieve educational goals. Learning must be managed creatively by educators to create a conducive atmosphere for students to raise students' motivation and interest in learning (Lubis \& Ikhsan, 2015; Yarifah \& Sumardi, 2015). In today's era, technology is needed to innovate the learning process in the classroom and outside the classroom.

Based on observations and interviews conducted at SD Negeri Keteleng 02 Batang, teachers in grade five SD have implemented learning integrated with technology. The problems experienced are that the intensity is still small and has limited supporting media owned by schools and students such as gadgets, computers, or inadequate internet networks. Currently, SD Negeri Keteleng 02 Batang has implemented online learning or termed Elearning. In the E-learning learning process, the teacher does not meet face to face with students, even though in the learning process, the role of the teacher in schools is very important in addition to teaching and educating students. Currently, if students are at home, each E-learning-based learning media is used by teachers. The WhatsApp application can be opened by students at home using their respective laptops or smartphones. Learning activities start from attendance, school assignments until the material is explained through the available applications. This activity makes it difficult for the teacher to check or control student activities during the applied E-learning. Of course, E-learning has various impacts, both negative and positive impacts.

Learning technology continues to develop along with the times. In the implementation of daily learning, we often encounter technological developments in the world of education. Learning in today's era is growing rapidly, especially in learning technology (Albiladi, 2019; Siregar \& Manurung, 2020). E-learning is an information and communication technology that enables students to learn anytime and anywhere (Kalantarrashidi, Mohammadpour, \& Sahraei, 2015; Lukitasari, Purnamasari, Utami, \& Sukri, 2019). E-learning has become popular in the world of education today, along with the rapid growth of information technology. The use of E-learning in the educational process has succeeded in contributing to a certain extent in improving the quality of education and improving the technical skills of students, even teachers or lecturers. The use of E-learning in everyday learning usually uses a combination of audio/data, video/data, and audio/video technologies (Rosy et al, 2018; Soni et al., 2018).

E-learning changes the way students learn who used to use books or teacher guidance as a source of media to obtain information but with the times. E-learning can make it all easy by utilizing information technology that can be accessed via the internet (Arifuddin, Suwatra, \& Mahadewi, 2020; Garad, Al-Ansi, \& Qamari, 2021). The purpose of E-learning is to facilitate learning wherever and whenever tailored to students. E-learning is also used to make it easier to receive knowledge and improve students' skills (Darmawan, 2014; Garad et al., 2021). E-learning provides all the conveniences provided, but it cannot eliminate the role of a teacher in learning in the classroom. Previous research stated that E-learning could provide students with ease in learning (Tafqihan, 2011). The findings of previous research regarding E-learning also state that E-learning can improve students' abilities (Aulia, Poedjiastoeti, \& Agustini, 2018). There has been no in-depth study on the impact of Elearning on elementary school students. This study aims to analyze E-learning learning in fifth-grade elementary school students.

\section{Methods}

This type of research is qualitative research. This research has been carried out in elementary schools, focusing on SDN Keteleng 02 Batang. As an initial interview and several resource persons involving teachers at the school. The research was carried out in the even 
semester of the 2019/2020 school year. Data collection techniques are the most strategic step in research because the main purpose of research is to obtain data. The techniques used to collect data in this study were observation, interviews, documentation, and questionnaires. Observations were made by observing learning activities, location, physical condition, facilities, and infrastructure. Observing the most important thing is observing the conditions when learning E-learning in fifth-grade students at SD Negeri Keteleng 02 Batang. In this study, interviews were conducted with the fifth-grade teacher as the person in charge of the class and the fifth-grade students of SD Negeri Keteleng 02 Batang. Document materials used as data sources to support this research are photographs related to e-learning learning at SD Negeri Keteleng 02 Batang. In this study, the respondents in collecting data through a questionnaire (questionnaire) were the fifth-grade students of SD Negeri Keteleng 02 Batang as the research sample. This questionnaire is in the form of open or closed questions or statements that respondents will fill out in statements, good, very good, not good, and very bad. The instrument used to collect data is a questionnaire. The instrument was used at the time of the interview, which contained several questions as an interview guide. The interview used by the researcher is a structured interview. With this structured interview, each respondent was asked a question. The technique used in analyzing the data is descriptive qualitative. The research was conducted by describing the data obtained in words or sentences separated for categories in obtaining conclusions. The data analysis technique in this study used three data acquisition procedures, namely data reduction, data presentation, and data verification.

\section{Results and Discussion}

Learning is an activity of acquiring and conveying knowledge between teachers and students. Learning in schools is an important thing to support students' abilities in the future. Learning requires a lot of innovation it (Abhyasari, Kusmariyatni, \& Agustiana, 2020; Sulianto et al, 2019). In implementing daily learning, we often encounter technological developments in education, as is often done by teachers, namely combining technological tools in the learning process. In this case, the use of media and technology can help students to understand the material presented by the teacher (Sunismi, 2015; Wulandari, Sudatha, \& Simamora, 2020; Yusnia, 2019). The development of technology is growing rapidly so that teachers are required to use technology in learning. If teachers ignore this, students will be left behind with a lot of information obtained (Hafsah, Rohendi, \& Purnawan, 2016; Kuswanto \& Walusfa, 2017). Thus, the role of technology itself is very important in the learning process. One learning process utilizes technology in E-learning (Rosy et al., 2018; Soni et al., 2018). E-learning is considered to improve the quality of education, improve students' technological skills in schools, and even affect teachers. It happens because Elearning utilizes technological media that develops in the learning process itself to help the learning process at school. Of course, the application of E-learning has various impacts on learning, especially for students and teachers (Arifuddin et al., 2020; Garad et al., 2021). This e-learning has been implemented at SD Negeri Keteleng 02 Batang.

Based on the research results at SD Negeri Keteleng 02 Batang, it is related to the Elearning learning process in fifth grade. Data obtained in this class teachers and students use E-learning learning based on the Zoom application and Whatsapp. This application was chosen because it can function as a provider of convenience in delivering material to students. It can be used remotely, avoid direct physical contact, involve the human senses such as the senses of sight and hearing, attract students' attention, arouse students' motivation and interest in learning, and make learning more meaningful. The first E-learning learning process in class $\mathrm{V}$ was carried out by the teacher, namely the teacher's presence to students by sending their photos that were already wearing neat clothes and ready to receive learning, 
sent not later than 08.00 WIB. After that, the teacher's explanation will be delivered through the Zoom application by sharing the Zoom link with students to join in as a face-to-face meeting. The teacher asks students to pay close attention to the teacher's explanation. The teacher explains the material based on the theme book, which the students also own. Students who do not understand the material presented by the teacher through the video can ask questions in the question and answer session, which is welcome by the teacher.

Meetings via the Zoom application take 40 minutes, after which the teacher gives assignments to students via the Whatsapp application. It uses Whatsapp and Zoom applications very closely related to the E-learning learning process at SD Negeri Keteleng 02 Batang. The teacher asks students to do assignments independently in their respective places by the teacher. The process of working on a given task has a collection time limit ranging from 2 to 3 hours of work. Assignments that students have completed can be collected through photos sent to the Whatsapp application. The teacher gives appreciation to students who have done and submitted assignments in the form of praise. The learning process is completed according to the hours specified in the school. When carrying out E-learning, the teacher uses the method with lectures, assignments. The teacher explains the material to the Zoom application students for lecture activities, and students pay attention to the teacher's explanation. The teacher gave the assignment through the Whatsapp application because the application to be easier to use.

Students seemed interested and enthusiastic about the E-learning delivered by the teacher. Students will be enthusiastic about learning activities (Hignasari \& Supriadi, 2020; Tafqihan, 2011). Students work on the assignments given by the teacher with enthusiasm and are collected on time. A sense of independence arises in students because being away from the teacher makes students have to solve problems independently. Students are required to be active independently by seeking material support from sources other than the teacher. Students' independence can be seen from students' attention, discipline, and participation in every E-learning learning process. It can be concluded that E-learning can increase students' activeness and independence in learning (Kurtz, Tsimerman, \& Steiner, 2014; Putra \& Sudarti, 2015). The E-learning learning process has benefits that can facilitate the transfer of knowledge from teachers to students remotely (Irawan, 2018; Pratiwi, Suartama, \& Tegeh, 2016). Using the internet network and applications, helping teachers and students meet faceto-face and carry out the E-learning learning process as a substitute for conventional learning in the classroom as usual. The E-learning learning process utilizes modern technological developments and requires an internet network to make it easier for teachers to transfer knowledge from teachers to students (Alfi, Sumarmi, \& Amirudin, 2016; Divayana, Hendra, Suyasa, 2016). But of course, this can hurt the learning process. It can be a barrier to student learning because it prevents teachers from achieving learning goals. Based on the results of the data obtained from research conducted at SD Negeri Keteleng 02. It was found that there were positive and negative impacts in the learning process of E-learning to students at SD Negeri Keteleng 02 Batang.

The positive impact of E-learning learning is, 1) Students become independent in dealing with every problem. It happens when students are far from the teacher's direct observation, only through the user application. Making students have to work independently in solving the problems they face. 2) The learning process becomes more flexible which can be accessed from anywhere through gadgets. It can make students comfortable to create enthusiasm and motivation for students to learn (Soni et al., 2018; Usman, 2018; Utami, 2017). 3) Easy to access and find information needed by students. Utilization of the internet network makes it easier for students to access additional material needed if it is felt that the teacher's explanation has not been understood (Hermawanto, Kusairi, \& Wartono, 2013; Vernadakis et al, 2012). 
The negative impacts of E-learning are, 1) The explanation of the material delivered by the teacher to students through the Zoom and Whatsapp applications is felt by students to be quite lacking. It happened because transferring information from the teacher to the students was hampered by the quality of the signal or the gadget used to jam the teacher's explanation video. 2) Requires support facilities that are not cheap such as a good smartphone or laptop (Kalantarrashidi et al., 2015; Purnomo, Ratnawati, \& Aristin, 2016). It is because Elearning uses applications to connect teachers and students. 3) Interaction between teachers and students is hampered. This interaction is very much needed in the learning process because teachers in schools play a role as teachers and student educators. The results of this study support the findings of research on the effectiveness of E-learning on students. Elearning can increase students' independence in learning (Rosy et al., 2018). Then the research findings on E-learning can improve students' critical thinking skills (Putra \& Sudarti, 2015).

\section{Conclusion}

E-learning can increase students' motivation and interest in learning more actively. Elearning is more flexible and can be accessed from anywhere. Can make students more independent in problem-solving. Students' independence can be seen from students' attention, discipline, and participation in every E-learning learning process. The obstacle faced by students is the lack of supporting technology facilities for this learning process, such as the quality of gadgets and signals in the area around the school

\section{References}

Abhyasari, N. P., Kusmariyatni, N. N., \& Agustiana, I. G. A. T. (2020). Pengaruh Pembelajaran Berpendekatan Saintifik Berbasis Masalah Terhadap Disiplin dan Hasil Belajar IPA. Mimbar PGSD Undiksha, 8(1), 111-122. https://doi.org/http://dx.doi.org/10.23887/jjpgsd.v8i1.24547.

Albiladi, K. (2019). Blended Learning in English Teaching and Learning: A Review of the Current Literature. Journal of Language Teaching and Research, 10(2), 232-238. https://doi.org/http://dx.doi.org/10.17507/j1tr.1002.03.

Alfi, C., Sumarmi, S., \& Amirudin, A. (2016). Pengaruh Pembelajaran Geografi Berbasis Masalah Dengan Blended Learning Terhadap Kemampuan Berpikir Kritis Siswa SMA. Jurnal Pendidikan Teori, Penelitian, Dan Pengembangan, 4(1). https://doi.org/http://dx.doi.org/10.17977/jp.v1i4.6203.

Arifuddin, Suwatra, \& Mahadewi. (2020). Pengembangan Konten E-learning Berorientasi Pendidikan Karakter Pada Mata Pelajaran Seni Budaya. Jurnal Edutech Undiksha, 8(2). https://doi.org/http://dx.doi.org/10.23887/jeu.v8i2.28942.

Aulia, E. V., Poedjiastoeti, S., \& Agustini, R. (2018). The Effectiveness of Guided Inquirybased Learning Material on Students' Science Literacy Skills. Journal of Physics: Conference Series, 947, 1-7. https://doi.org/10.1088/1742-6596/1088/1/012106.

Azizah, S., Khuzaemah, E., \& Rosdiana, I. (2017). Penggunaan Media Internet eXe-Learning Berbasis Masalah pada Materi Perubahan Lingkungan untuk Meningkatkan Hasil Belajar Siswa dalam kehidupan sehari-harinya dan juga psikomotor ( keterampilan ) siswa . Proses belajar dapat materi dan bahan belajar yang. Scientiae Educatia: Jurnal Pendidikan Sains, (2005), 197-213. https://doi.org/DOI: http://dx.doi.org/10.24235/sc.educatia.v6i2.1957.

Darmawan, D. (2014). Pengembangan E-learning Teori dan Desain. Bandung: Remaja Rosakarya.

Darmayasa, I. K., Jampel, N., \& Simamora, A. H. (2018). Pengembangan E-Modul Ipa 
Berorientasi Pendidikan Karakter Di Smp Negeri 1 Singaraja. Jurnal Edutech Undiksha, 6(1), 53-65. https://doi.org/http://dx.doi.org/10.23887/jeu.v6i1.20267.

Divayana, Hendra, D. G., Suyasa, W. A., \& Sugihartini, N. (2016). Pengembangan Media Pembelajaran Berbasis Web Untuk Matakuliah Kurikulum dan Pengajaran di Jurusan Pendidikan Teknik Informatika Universitas Pendidikan Ganesha. Jurnal Nasional Pendidikan Teknik Informatika (JANAPATI), 5(3), 149-157. https://doi.org/http://dx.doi.org/10.23887/janapati.v5i3.9922.

Garad, A., Al-Ansi, A. M., \& Qamari, I. N. (2021). The Role Of E-Learning Infrastructure And Cognitive Competence In Distance Learning Effectiveness During The Covid-19 Pandemic. Cakrawala Pendidikan, $40(1)$. https://doi.org/https://doi.org/10.21831/cp.v40i1.33474.

Hafsah, Rohendi, \& Purnawan. (2016). Penerapan Media Pembelajaran Modul Elektronik Untuk Meningkatkan Hasil Belajar Siswa Pada Mata Pelajaran Teknologi Mekanik. Journal of Mechanical Engineering Engineering Education, 3(1). https://doi.org/https://doi.org/10.17509/jmee.v3i1.3200.

Hermawanto, Kusairi, \& Wartono. (2013). Pengaruh Blended Learning terhadap Penguasaan Konsep dan Penalaran Fisika Peserta Didik Kelas X. Jurnal Pendidikan Fisika Indonesia, 9(57), 67-76. https://doi.org/https://doi.org/10.15294/jpfi.v9i1.2582.

Hignasari, L. V., \& Supriadi, M. (2020). Pengembangan E-Learning dengan Metode Self Assessment Untuk Meningkatkan Hasil Belajar Matematika Mahasiswa Universitas Mahendradatta. Jurnal Kependidikan, 6(2). https://doi.org/https://doi.org/10.33394/jk.v6i2.2476.

Irawan, H. (2018). Keefektifan E-Learning Sebagai Media Pembelajaran (Studi Evaluasi Model Pembelajaran E-Learning Smk Telkom Sandhy Putra Purwokerto). Jurnal Inovasi Teknologi Pendidikan, 5(1), 1-11. https://doi.org/https://doi.org/10.21831/jpv.v3i1.1584.

Kalantarrashidi, S. A., Mohammadpour, E., \& Sahraei, F. (2015). Effect of Blended Learning Classroon Environment on Student's Satisfaction. Journal of Educaion and Training Studies, 3(5), 225-230. https://doi.org/https://doi.org/10.11114/jets.v3i5.1013.

Kurtz, G., Tsimerman, A., \& Steiner, O. (2014). The Flipped Classroom Answer to Future Learning? European Journal of Open, Distance and E-Learning, 17(2). https://doi.org/https://doi.org/10.2478/eurodl-2014-0027.

Kuswanto, J., \& Walusfa, Y. (2017). Pengembangan Multimedia Pembelajaran pada Mata Pelajaran Teknologi Informasi dan Komunikasi Kelas VIII. Innovative Journal of Curriculum and Educational Technology IJCET, 6(2), 58-64. https://doi.org/https://doi.org/10.15294/ijcet.v6i2.19335.

Lapisa, Basri, Arif, \& Saputra. (2017). Peningkatan Kompetensi Siswa Melalui Pelatihan Auto CAD. Jurnal Inovasi Vokasional Dan Teknologi, 17(2). https://doi.org/https://doi.org/10.24036/invotek.v17i2.82.

Lubis, \& Ikhsan. (2015). Pengembangan Media Pembelajaran Kimia Berbasis Android Untuk Meningkatkan Motivasi Belajar Dan Prestasi Kognitif Peserta Didik SMA. Jurnal Inovasi Pendidikan IPA, 1(2). https://doi.org/https://doi.org/10.21831/jipi.v1i2.7504.

Lukitasari, Purnamasari, Utami, \& Sukri. (2019). Blended-Problem-Based Learning: How its impact on students' critical thingking skills? Jurnal Pendidikan Biologi Indonesia, 5(3), 425-434. https://doi.org/https://doi.org/10.22219/jpbi.v5i3.10048.

Maesaroh, S. (2013). Peranan Metode Pembelajaran Terhadap Minat Dan Prestasi Belajar Pendidikan Agama Islam. Jurnal Kependidikan, 1(1). https://doi.org/https://doi.org/10.24090/jk.v1i1.536.

Maunah, B. (2015). Implementasi Pendidikan Karakter dalam Pembentukan Kepribadian Holistik Siswa. Jurnal Pendidikan Karakter, 1(1). 
https://doi.org/https://doi.org/10.21831/jpk.v0i1.8615.

Mustikaningrum, G., Pramusinta, L., Ayu, S., \& Umar, M. (2020). Implementasi Pendidikan Karakter Terintegrasi Kurikulum Dan Metode Pembelajaran Pada Masa Pandemi Covid-19. AULADUNA: Jurnal Pendidikan Dasar Islam, 7(2), 154-164. https://doi.org/https://doi.org/10.24252/10.24252/auladuna.v7i2a5.2020.

Nurkholis. (2013). Pendidikan dalam Upaya Memajukan Teknologi. Jurnal Kependidikan, 1(24). https://doi.org/https://doi.org/10.24090/jk.v1i1.530.

Pratiwi, I., Suartama, I. K., \& Tegeh, I. M. (2016). Pengembangan E-Learning dengan Model Prototype Berorientasi Model Pembelajaran Inquiry Siswa Kelas VII SMPN 2 Negara. Jurnal Edutech Undiksha, 4, No 2. https://doi.org/http://dx.doi.org/10.23887/jeu.v4i2.7615.

Purnomo, Ratnawati, \& Aristin. (2016). Pengembangan Pembelajaran Blended Learning $\begin{array}{llll}\text { Pada Generasi } & \text { Z. JTP2JPS, } & \text { l(1). }\end{array}$ https://doi.org/http://dx.doi.org/10.17977/um022v1i12016p070.

Putra, P. D. A., \& Sudarti. (2015). Pengembangan Sistem E-Learning untuk Meningkatkan Keterampilan Berpikir Kritis Mahasiswa Pendidikan Fisika. Jurnal Fisika Indonesia, 19(55), 45-48. https://doi.org/https://doi.org/10.22146/jfi.24373.

Rosy, B., Ranu, M. E., Nugraha, J., \& Handini, H. T. (2018). Pelatihan Media Pembelajaran Berbasis E-Learning, Schoology Bagi Guru SMK Program Keahlian Administrasi Perkantoran Di Kabupaten Jombang Jawa Timur. Jurnal Pemberdayaan Masyarakat Madani, 2(2). https://doi.org/https://doi.org/10.21009/JPMM.002.2.02.

Siregar, \& Manurung. (2020). Pengaruh Blended Learning terhadap Kreativitas Mahasiswa Calon Guru di Universitas Negeri Medan. Edumatika: Jurnal Riset Pendidikan Matematika, 3(1). https://doi.org/https://doi.org/10.32939/ejrpm.v3i1.485.

Soni, Hafid, Hayami, Fatma, Wenando, Amien, ... Mukhtar. (2018). Optimalisasi Penggunaan Google Classroom, E-Learning \& Blended Learning sebagai Media Pembelajaran Bagi Guru dan Siswa di SMK Negeri 1 Bangkinang. Jurnal Pengabdian Untukmu Negeri, 21. https://doi.org/https://doi.org/10.37859/jpumri.v2i1.361.

Sulianto, J., Sunardi, Anitah, S., \& Gunarhadi. (2019). Analisis Implementasi Pembelajaran di Sekolah Dasar pada Pengembangan Model Advance Organizer berbasis Pendekatan Open Ended untuk Meningkatkan Penalaran Siswa. International Journal of Elementary Education Universitas Pendidikan Ganesha, 3(4), 396-403. https://doi.org/http://dx.doi.org/10.23887/ijee.v3i4.21312.

Sunismi. (2015). Developing Guided Discovery Learning Materials Using Mathematics Mobile Learning Application As An Alternative Media For The Students Calculus II. Cakrawala Pendidikan, 34(5). https://doi.org/https://doi.org/10.21831/cp.v3i3.7340.

Suyadi, S. (2018). Pendidikan Islam Anak Usia Dini Dalam Perspektif Neurosains: Robotik, Akademik, Dan Saintifik. Jurnal Penelitian Pendidikan Islam, 13(2). https://doi.org/http://dx.doi.org/10.21043/edukasia.v13i2.3255.

Tafqihan, Z. (2011). Karakteristik Dan Pemilihan Media Pembelajaran Dalam E-Learning. Cendekia: Jurnal Kependidikan Dan Kemasyarakatan, 9(2), 141-154. https://doi.org/https://doi.org/10.21154/cendekia.v9i2.871.

Taufik, A. (2019). Perspektif Tentang Perkembangan Sistem Pembelajaran Jarak Jauh Di Kabupaten Kutai Kartanegara Kalimantan Timur. Jurnal Pendidikan\&Konseptual, 3(2), 88-98. https://doi.org/DOI:http://doi.org/10.28926/riset_konseptual.v2i4.111.

Usman. (2018). Komunikasi Pendidikan Berbasis Blended Learning Dalam Membentuk Kemandirian Belajar. Jurnal Jurnalisa, 4(1), 136-150. https://doi.org/https://doi.org/10.24252/jurnalisa.v4i1.5626.

Utami, I. S. (2017). Pengujian Validitas Model Blended Learning di Sekolah Menengah 
Kejuruan. Jurnal Ilmiah Pendidikan Teknik Elektro, 2(1), 1-10. https://doi.org/http://dx.doi.org/10.30870/volt.v2i1.963.

Vernadakis, Giannous, Derri, Michalopoulos, \& Kioumourtzoglou. (2012). The impact of blended and traditional instruction in students performance. In Procedia Technology, 1(1), 439-443. https://doi.org/https://doi.org/10.1016/j.protcy.2012.02.098.

Widowati, H. (2011). Penerapan Pembelajaran Kooperatif Model Examples Non Examples Dan Stad Pada Mata Kuliah Struktur Hewan Program Studi Pendidikan Biologi. Bioedukasi: Jurnal Pendidikan Biologi Fkip Um Metro, 2(1). https://doi.org/https://doi.org/10.24127/bioedukasi.v2i1.202.

Wirasasmita, \& Hendriawan. (2020). Analisis Efisiensi Kinerja Pendidik terhadap Hasil Pembelajaran Pendidikan Jasmani pada Siswa Sekolah. Mimbar Pendidikan, 5(1), 7590. https://doi.org/https://doi.org/10.17509/mimbardik.v5i1.24152.

Wulandari, Sudatha, \& Simamora. (2020). Pengembangan Pembelajaran Blended Pada Mata Kuliah Ahara Yoga Semester II di IHDN Denpasar. Jurnal Edutech Undiksha, 8(1), 1-15. https://doi.org/http://dx.doi.org/10.23887/jeu.v8i1.26459.

Yarifah, \& Sumardi. (2015). Pengembangan Model Pembelajaran Malcolm's Modeling Untuk Meningkatkan Keterampilan Berpikir Kritis Dan Motivasi Belajar Siswa. Jurnal Inovasi Pendidikan IPA, I(2), 237-247. https://doi.org/https://doi.org/10.21831/jipi.v1i2.7510.

Yusnia, Y. (2019). Penggunaan Media Video Scribe Dalam Pembelajaran Literasi Sains Untuk Mahasiswa PGPAUD. Cakrawala Dini: Jurnal Pendidikan Anak Usia Dini, 10(1), 71-75. https://doi.org/https://doi.org/10.17509/cd.v10i1.17436. 